\title{
THE PROBLEM OF CONTEXTUALIZING A PRESTIGIOUS YET NON-DIVINE JESUS OF ISLAMIC TRADITION: \\ Theorizing a Radical Transition in the Course of Christology from the New Testament to the Qur'an
}

\author{
Syed M. Waqas \\ Cincinnati Christian University, OHIO, USA \\ Email: syed.waqas@ccuniversity.edu
}

\begin{abstract}
This article addresses the question of the messianic motif of Christianity making its way into the Qur'an without wearing a badge of high New Testament Christology. It attempts to explore and understand a potentially underlying connection among the Islamic 'Isā, the New Testament Jesus, and the Jewish messiah in a quest for the configuration of a historical Christ through the ideological and historical minefields that exist between the Islamic and the JudeoChristian Scriptures. The person of Jesus is, therefore, understood to be historical in the article without positing a response to the fundamental questions raised by the historical Jesus skepticism. What I will try to avoid in the following pages, on the contrary, is to treat and brand the Qur'anic portrayal of Jesus as a "stand-alone" concept-indifferent to the historical context of the Bible-hanging in a theological balance, as some critics would be inclined to call it. The article is linearly structured according to the major Qur'anic precepts and concepts developed around the person of Jesus through its text, which originally do not follow a particular sequence. A comparative study of Islamic Jesus against a two-pronged history of the concept is carried out for a critical analysis of the characterization of Islamic Jesus and the received concept of messiah. Such an analysis is important particularly on two fronts: comparison with the Judeo-Christian Bible and comparison with the orthodox Islamic position in certain aspects that fall outside the Qur'anic provenance. The life and ministry of Jesus pictured in the present article is, for the most part, a reconstruction of the important notion of Christology from within the Qur'an without breaking it down to a form of reductionism capitalizing on rudimentary borrowing from an external source. ${ }^{1}$
\end{abstract}

Keywords: Jesus, the Course of Christology, the New Testament, the Qur'an

DOI: http://dx.doi.org/10.20414/ujis.v25i1.439 


\section{Introduction}

'ISĀ IBN MARYAM, "Jesus, the son of Mary," is the name employed by the Qur'an, the sacred Scripture of Islam, throughout its text for the founder of historical Christianity, the man known as Christ Jesus in the New Testament. ${ }^{2}$ In spite of its metronymic nature, as it turns out, this long name is not treated as metronymic in Islam in the proper sense of the word because ibn Maryam occurs in the Qur'an to distinguish Jesus' identity in the same way as a personal name does. This particular construction, from an Islamic perspective, emphasizes and reinforces the - traditional (historical) Roman Catholic - stipulation of Mary's immaculate character and Jesus' virginal birth within the purview of the Qur'anic conscience. ${ }^{3}$ The Qur'an recognizes Jesus as one of the mightiest prophetic-messengers of God (Arabic, rasūl) in a long chain of divine emissaries. ${ }^{4}$ This unbroken chain commences with the Prophet Nūh-the biblical Patriarch Noah. Noah is accepted as the first and Muhammad being the last of the messengers endowed with a covenant, whereas Adam is regarded as the father of humanity and the first of the prophets who was permitted to

1 The Islamic scripture will be referred to as the Qur'an throughout the article. The appellation, Holy Qur'an, is less formally used among both Muslims and non-Muslims in academic writings, because there is no textual reference to such a particular construction in the Qur'an itself. The tendency of terming the Islamic scripture as the Holy Qur'an is, nevertheless, becoming more commonplace in Islamic writings in the English language following the precedent of the Judeo-Christian scriptural title, Holy Bible. The Qur'an is also written as the Koran in the American English, which is not being followed in the present article. Moreover, I have not restricted myself to one particular translation of the Qur'an, for such a thing does not fulfill the requirement of an academic research with reference to the transmission of the Islamic scripture's message and meaning. However, the article has preferably benefited from the renowned English translation of 'Abdullah Yusaf 'Ali, The Meaning of the Holy Qur'an.

\section{2 عيسن ابن مريم، المسيح ورسول الله}

ii. The New Testament addresses Jesus both in Greek (Inooṽs) and Aramaic

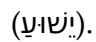

3 Baidawi in Geoffrey Parrinder, Jesus in the Qur'an (New York: Oxford University Press, 1977), 22.

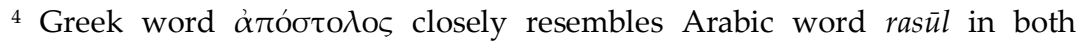
meaning and the responsibility. 
communicate with God without having been made to sign a covenant. $^{5}$

Jesus is, moreover, addressed with the historically-charged epithet of al-masinh, "the Christ," in the worldview brought forth by the Qur'an, which may be understood as a unique Christological recapitulation of an ancient religious concept. ${ }^{6}$ It is an honorific title allegedly conferred upon, and strictly reserved for the historical person of Jesus alone, as the text indicates. The Qur'an does not seem to have used the epithet of al-masin as a surname or a title assumed by a military leader, for it occurs in a fashion that speaks of Jesus' ordination by God to the highest spiritual status even prior to his birth. ${ }^{7}$ The glad tidings given to Mary by the angels in Sūrah Âl 'Imrān 3:45 include the word masīh reminiscing the Gospel of Luke 2:11 rather than using the personal name 'Isā, "Jesus," as it is the case in Luke 2:21, which reflects Qur'an's revisionist approach towards the New Testament. ${ }^{8}$ By

${ }^{5}$ The exception in this case may be made of the forbidden tree-a negative imperative command, nahi, which entails all the dynamics of a personal covenant. In the biblical fashion, in fact, the Qur'an also maintains that Adam and his companion were told to stay away from a certain tree, which was the first mutual agreement between God and humanity. Arabic word used in the Qur'an for covenant is mìthāq, which does not occur directly with reference to Adam, though it does make an appearance with reference to the "children of Adam" in Sürah A'rāf 7:172. Surah Țāhā 20:115, contrarily, makes a mention of God's "covenant" with Adam, but the Arabic word used in this context is 'ahd, "pact," rather than mithāq, which does not imply a collective covenant, such as one made with the nation of Israel. See Vincent J. Cornell, Voices of Islam: Voice of Tradition (Westport, CT: Praeger Publishers, 2007), 108-109.

${ }^{6}$ W. Richard Oaks Jr., The Cross of Christ (Lanham, MD: Lexington Books, 2020), 28.

7 The Qur'an contradicts with the Gospels (Matthew 3:16-17; Mark 1:10-11; Luke 3:21-22) on the ordination of Jesus as مسيح, "Christ," on the eve of his baptism by John the Baptist. In this sense, therefore, the Qur'an officially initiates the ministry of Jesus at the time of his birth.

8 The Arabic root بُشرىن (bushrā) is employed here to convey the "good news" of Jesus' birth to Mary. The same root occurs with reference to the "good news" of Muhammad's birth in Sürah Șaff 61:6 where the news is broken by none other than Jesus himself. Muslims identify this Qur'anic reference with $\pi \alpha \varrho \alpha ́ \kappa \lambda \eta \tau o \varsigma$ of John 14:16. More discussion will follow in the coming pages. See also 'Abdul Ahad Dawud, Muhammad in the Bible, vol. 2 of Muhammad in World Scriptures (Kuala Lumpur, Malaysia: Islamic Book Trust, 2006), 196-205. 
acknowledging Jesus as the Christ, therefore, the Qur'an sets up a unique tradition of Christology inherently received from Christianity but revamped and radically reinterpreted through Islam's own theological lens in order to bring forth a consistently Islamic construct. The new construct was built out of a received tradition but was completely redefined using a theological-cumhistorical argument that would develop along both apologetic and polemical lines of reasoning.

\section{Complexity of Comparison}

In spite of the numerous similarities, Jesus of the Qur'an is radically different from that of the New Testament, for the persona and career of Jesus do indeed bear major theological and historical differences between the two portrayals of him deep beneath the surface. The fundamental difference, however, stems from the premise upon which the ministry of Jesus is built within the teleological consciousness of the two scriptures. The Qur'an, notwithstanding the acknowledgement of the virginal birth and miraculous powers of Jesus, denies the doctrine of sonship and does not canonize and regulate the status of the "Son of God" for Jesus. Following its strict code of divine unity (Arabic, tawhìd), the Islamic scripture carefully avoids condoning such a Christian notion that might give space to the Trinitarian principle of Jesus' divinity incarnated in his person and translated into his Messianism. Such a notion is, in fact, emphasized in the theology of the Gospel of John (3:16). It maintains that God cannot have a son and therefore Jesus is only 'abd-Alläh, "servant of God," in the first place and a prophetic-messenger in the second. ${ }^{9}$ It is, therefore, crucial to analyze what the Qur'an postulates on the subject in question, which highlights a huge digression from the

9 This particular notion partially corresponds with Matthew 12:18, Mark 1:11, Acts 3:13 and 3:26. The Arabic word عبد ('abd), "servant," is the same word

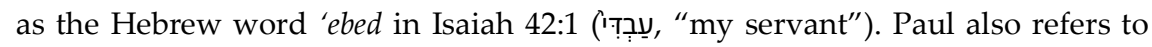
this in Philippians 2:7 saying, "he made himself nothing by taking the very nature of a servant." Paul uses the Greek word doúlos (doulos) here, which means "slave" or "servant." The other Greek term used in the New Testament with reference to servant is taī (pais), which is often translated as "son." The best Qur'anic cross-reference in this context is chapter 112, Sūrah Ikhlāṣ. 
Christian theology in the development of Islamic theology. The Qur'an comments on the Christian doctrine of sonship in the following words:

The Christians say the Messiah is the Son of God that is a saying from their mouths. (Sūrah Tawbah 9:30)

The highest form of a polemical argument that corresponds with all such ideas about God, however, proceeds from one of the shortest chapters of the Qur'an that constitutes Islam's foundational principle of the nature of Godhead. It is the Sürah 112, which reads:

Say: He is Allah, the One and Only. Allah, the Eternal, the Absolute. He begets not, nor is He begotten. And there is none like unto Him. (Sürah Ikhlāṣ 112:1-5)

Unlike the Gospels, there is a complete lack of a linear or a historical biography of Jesus in the Qur'an. It does not tell the entire story of Jesus in one place, for there is no particular chapter in the Qur'an where, particularly in a fashion of the Synoptic Gospels, the whole story is given a biographic snapshot by following a straight storyline. References to the birth, childhood, teachings, ministry, miracles, and important events of the life of Jesus are scattered throughout the Qur'anic text, which makes it extremely difficult for an ordinary reader to piece them all together and get a full story. Jesus is mentioned both directly and indirectly in a total of 93 verses of the Qur' an out of a total of 6236 verses. ${ }^{10}$ In some other places, moreover, Jesus is indirectly spoken of as the one Nazarene, and his followers are addressed almost exclusively as nașārāa, "the Nazarenes," which occurs no less than fourteen times. The Qur'an does not, however, bring the traditional Arabic word into reference used for the followers of Christ, al-masīhiyyūn, "the Christians."11 In a similar fashion, moreover, the Disciples of Christ are granted a title not conventionally used in the Arabic language for a disciple. The

${ }^{10}$ Gregory A. Barker and Stephen E. Gregg, Jesus Beyond Christianity: The Classic Texts (Oxford: Oxford University Press, 2010), 84.

${ }^{11}$ See Sydney H. Griffith, "Al-Nașārā in the Qur'ān," in New Perspectives on the Qur'ān: The Qur'ān in Its Historical Context 2, ed. Gabriel Said Reynolds (New York: Routledge, 2011), 301-322. 
plural word that is used some 13 times in the Qur'anic text to reference the Disciples of Christ is hawäriyyūn, which, in Arabic lexicon, means "those who whiten the clothes by washing and beating." 12 The context of the term, nevertheless, dictates a more contextual meaning in the Qur'an and implies "close companions of Christ" who became his "fair helpers" in the course of his prophetic movement. ${ }^{13}$

It is beyond a reasonable doubt to acknowledge that the Qur'an accords immense respect to both Jesus and his mother, Mary. Interestingly, the only Qur'anic chapter named after a woman is the $19^{\text {th }}$ chapter, Sūrah Maryam, which is named after Jesus' mother, Mary. It, perhaps, represents a historical picture and reflects the dialectics of the period of Islamic revolution when evolving Islamic religious paradigm incorporated such elements of Christianity that were a source of discord between opposing religious groups. ${ }^{14}$ It is, therefore, critical to recognize that Mary does hold the highest Qur'anic standard of purity and is defended against the Jewish stigmatization of her in rabbinic literature with reference to Jesus' virginal birth. The Qur'an stipulates this position in the following verses:

Allah hath set the seal on their (Jews') hearts for their blasphemy, and little is it they believe; that they rejected Faith; that they uttered against Mary a grave false charge. (Sūrah Nisā 4:155-156)

The Islamic scripture goes even farther in defending Mary in a calculated move to develop a compelling apologetic discourse, declaring (a) "she guarded her chastity," and that (b) "God has chosen and sanctified her above the women of all nations." 15 This

12 Edward William Lane, Arabic-English Lexicon, vol. 2 (Cambridge: Islamic Text Society, 1984) art. HWR.

13 'Abdul Mannan 'Omar, Dictionary of the Qur'ān: Arabic-English, 2nd ed. (Hockessin: Noor Foundation International, 2005), 141, art. HWR.

${ }^{14}$ Jesus is often referred to with a stigmatizing designation as Ben Pandira, "Son of Pandira," in the Talmud because the rabbinic polemics does not acknowledge the virgin birth of Jesus and declares that Miriam, "a woman's hairdresser," was indeed married, but she conceived the baby "Yeshu" by another man. See David Klinghoffer, Why the Jews Rejected Jesus (New York: Three Leaves Press, 2005), 142.

${ }^{15}$ (a) Sūrah Anbiyā 21:92; (b) Sūrah Āl ‘Imrān 3:42. 
proclamation prepares the stage for launching a grand ministry of Jesus whose vision the Qur'an and the New Testament each develops differently.

Jesus, as the Qur'an maintains, was sent to the "Children of Israel" (Arabic, Ban̄i Isrä'îl) to command them in righteousness and bring them back from their ungodly ways to the truth revealed in the Torah. ${ }^{16}$ Thus, Jesus almost always speaks in the Qur'an within the contextual framework of the nation of Israel.

And (make him) a Messenger to the Children of Israel, "Indeed I have come to you...to attest the Law which was before me. And to make lawful to you part of what was (before) forbidden to you; I have come to you with a Sign from your Lord. So fear Allah, and obey me." (Sūrah Āl ‘Imrān 3:49-50)

\section{Christology versus the Mystery of Virgin Birth and Hidden Years}

The Qur'an sheds a good measure of light on the birth and childhood of Jesus in a manner that is noticeably different from the canonical Gospels of the New Testament. The Qur'an, in spite of not offering much detail, remains conservative in terms of preserving the prophecy and immaculate birth of Jesus in the overall presentation of its thesis of the ultimate religious path ordained. The Qur'an's language structure reflects an "eternal present continuum," which does not treat history in a chronological sequence. ${ }^{17}$ The style of the Qur'an is, therefore, neither historical nor biographic when it comes to addressing the person and ministry of Jesus Christ. This is also, though partly, true of other major characters named in the Islamic scripture. It will become obvious on a closer examination that the Qur'an

16 The Qur'an echoes Matthew 15:24 ("I was sent only to the lost sheep of Israel") in Sūrah 3:49-50 with the explicit connotation of limiting Jesus' ministry to the nation of Israel alone. Matthew 15:22-26 grants a context to this position maintained by Jesus in the following words: "A Canaanite woman from that vicinity came to him, crying out, "Lord, Son of David, have mercy on me! My daughter is demon-possessed and suffering terribly." Jesus did not answer a word. So his disciples came to him and urged him, "Send her away, for she keeps crying out after us." He answered, "I was sent only to the lost sheep of Israel." The woman came and knelt before him. "Lord, help me!" she said. He replied, "It is not right to take the children's bread and toss it to the dogs."

${ }^{17}$ Tarif Khalidi, The Muslim Jesus (Cambridge: Harvard University, 2001), 10. 
simply makes references to Jesus in accordance with a given situation in its dialogue with the Christian audience while telling anecdotes from a presumably historical life of Jesus. It seems more realistic to view the Qur'anic characterization of Jesus being ethical and theological, which is interlocked with its ethical-theological topoi and thematic framework. It is, therefore, not unrealistic to glean that Jesus maintains a close resemblance with Abraham, Moses, David, and John the Baptist in the Qur'an in terms of proclaiming and presenting his prophetic ministry. ${ }^{18}$

The birth story of Jesus is told in the $19^{\text {th }}$ chapter, Sürah Maryam, of the Qur'an. From an Islamic perspective, it is the most complete account of the birth of Jesus and his miracle of speaking in the cradle. The account, in fact, broadly resembles the story told in the Gospel of Luke (1:26-38). All other accounts are brief and pithy, which only function as a reference back to the account found in chapter 19. It is, therefore, important to take a look into it.

Relate in the Book (the story of) Mary, when she withdrew from her family to a place toward the East. She placed a screen (to screen herself) from them; then We sent her our angel, and he appeared before her as a man in all respects. She said: "I seek refuge from thee to (Allah) Most Gracious: (come not near) if thou dost fear Allah." He said: “Nay, I am only a messenger from thy Lord, (to announce) to thee the gift of a holy son. She said: "How shall I have a son, seeing that no man has touched me, and I am not unchaste?" He said: "So (it will be): Thy Lord saith, 'that is easy for Me: and (We wish) to appoint him as a Sign unto men and a Mercy from Us': It is a matter (so) decreed." So she conceived him, and she retired with him to a remote place. And the pains of childbirth drove her to the trunk of a palmtree: She cried (in her anguish): "Ah! Would that I had died before this! Would that I had been a thing forgotten and out of sight!" But (a voice) cried to her from beneath the (palm-tree): "Grieve not! For thy Lord hath provided a rivulet beneath thee; and shake towards thyself the trunk of the palm-tree: It will let fall fresh ripe dates upon thee. So eat and drink and cool (thine) eye. And if thou dost see any man, say (by gesture); 'I have vowed a fast to (Allah) Most Gracious, and this day will I enter into no talk with any human being."' At length she brought the (babe) to her people, carrying him (in her arms). They said: "O Mary! Truly an amazing thing hast thou brought! $\mathrm{O}$ sister of Aaron! Thy father was not a man of evil, nor thy mother a woman

${ }^{18}$ Sūrah Mā'idah 5:75, “Christ the son of Mary was no more than an apostle; many were the apostles that passed away before him. His mother was a woman of truth. They had both to eat their (daily) food. See how Allah doth make His signs clear to them; yet see in what ways they are deluded away from the truth!" 
unchaste!" But she pointed to the babe. They said: "How can we talk to one who is a child in the cradle?" He (Jesus) said: "I am indeed a servant of Allah. He hath given me revelation and made me a prophet; and He hath made me blessed wheresoever I be, and hath enjoined on me Prayer and Charity as long as I live; (He) hath made me kind to my mother, and not overbearing or miserable; so peace is on me the day I was born, the day that I die, and the day that I shall be raised up to life (again)!" Such (was) Jesus the son of Mary: (it is) a statement of truth, about which they (vainly) dispute. ${ }^{19}$ (Sūrah Maryam 19:16-34)

Surprisingly, there is no mention of Joseph, the carpenter, in the Qur'anic story of Jesus and Mary, nor is there a reference to Mary's betrothal..$^{20}$ In the classical commentaries of the Qur'an, such an absence of Joseph from the text is approached on ethical vis-à-vis theological grounds, maintaining, that such a companionship of Mary and Joseph before Jesus' birth does not fit within the moral-perfection-model upheld in the Qur'an. ${ }^{21}$ It could magnify, as seems evident from the language, the stigma of Jesus' (fatherless) birth and give in to the Jewish propaganda against Mary to the effect of purporting to maculate the moral character of both, the mother and the son. ${ }^{22}$ Every measure of care is thus taken to portray Mary as a perfectly chaste and upright embodiment of

19 The Qur'anic account of Jesus' birth shares various features with the canonical Gospels of Matthew and Luke. However, some of those features and nuances also bear resemblance with those found in the extracanonical sources, such as the Infancy Gospel of Mary and First Infancy Gospel of Jesus Christ. The Qur'an does not strictly follow the Gospels' pattern in telling the birth account of Jesus. An interesting question-and a logical one in the present scenario-one might want to ask at this stage is whether or not these anecdotes as told in the Qur'an were adopted from both canonical and extracanonical Gospels. If the answer is to be sought in the affirmative, we are left in a blank regarding the follow-up question if Muhammad, the Prophet of Islam, had an access to such a library of Christian resources beyond the orality of Arabian lore. For more on the infancy Gospels, see Christopher A. Frilingos, Jesus, Mary, and Joseph: Family Trouble in the Infancy Gospels (Philadelphia, PA: University of Philadelphia Press, 2017); Joseph Ratzinger, Jesus of Nazareth: The Infancy NarrativesPublishing, 2012, trans. Philip J. Whitmore (New York: Image Publishing, 2012).

${ }^{20}$ Gospel of Matthew reports that Mary was betrothed to Joseph (1:18).

${ }^{21}$ Parrinder, Jesus in the Qur'an, 23-24.

22 Sūrah Maryam 19:20, "She (Mary) said: "How shall I have a son, seeing that no man has touched me, and I am not unchaste?" - See also Sūrah Anbiyā 21:91, "And (remember) her who guarded her chastity: We breathed into her of Our spirit, and We made her and her son a sign for all peoples." 
womanhood to establish the virgin birth as a principle for the life of Jesus being a "sign of God." ${ }^{23}$ It is quite certain that the Qur'anic author does not "cut and paste" those received biblical stories, as some Orientalists might insist, but, in fact, redresses such materials to adapt the content to the new religious paradigm envisaged and laid out in the Qur'an. Understandably, an uncompromising development of the Qur'anic ethics amidst a conservative-minded Arabian society could not afford to put Mary in the custodianship of Joseph beyond wedlock, which, if accepted in its Synoptic narrative, would be tantamount to casting doubt on Mary's moral conduct. ${ }^{24}$ Contrarily, such a methodological approach is foreign to the Synoptic Gospels, especially the one written for the Jews, the Gospel of Matthew.

This is how the birth of Jesus the Messiah came about: His mother Mary was pledged to be married to Joseph, but before they came together, she was found to be pregnant through the Holy Spirit. Because Joseph her husband was faithful to the law, and yet did not want to expose her to public disgrace, he had in mind to divorce her quietly. But after he had considered this, an angel of the Lord appeared to him in a dream and said, "Joseph son of David, do not be afraid to take Mary home as your wife, because what is conceived in her is from the Holy Spirit. She will give birth to a son, and you are to give him the name Jesus, because he will save his people from their sins. (Matthew 1:18-21)

Approaching the subject from a critical angle requires raising an important question: did the Qur'anic transmitter ever get a chance to hear about any of the important characters, places, and events coinciding with the lifetimes of Jesus, such as Joseph, Paul, Peter, Judas, Bethlehem, Nazareth, Jerusalem, God as Father and Holy Spirit, Baptism, Last Supper, and the Church? Even a cursory reading in the Qur'an will reveal the fact that the narrator was,

23 In the presentation of Mary's image, the Qur'an bears remarkable resemblance with the apocryphal work of Protoevangelium of James, which glorifies Mary beyond traditional New Testament teachings. See Stephen J. Shoemaker, Mary in Early Christian Faith and Devotion (New Haven, MA: Yale University Press, 2016), 47, 276.

24 The anti-Christian attitude of the Jews scandalized Mary for the very event, virgin birth, that the Christians believed was a miracle. This practice of belittling and insulting Mary continued down through ages and found its way to the Jewish Talmud and homiletics, which rather strongly surfaced in the days of the Prophet of Islam. See footnote 14. 
relatively, better off in the Judeo-Christian religious tradition versus majority of the Arabs in the early seventh century. However, how far well-versed was he in this area is a matter still indebted to further research and exploration. It is noteworthy though that the earliest and purportedly the most authentic biography of the Prophet Muhammad, Sìrat Rasūl Allah by Muhammad ibn Ishāàq, includes a report from the court of the Abyssinian king, the Negus, which describes that the Christian king did, in fact, confirm the authenticity of the above quoted Qur'anic account of Jesus amidst his entourage of clergymen and courtiers..$^{25}$ Ibn Isḥāq says that Ja'far ibn Ṭayyār, a renowned Companion and cousin of Muhammad, went ahead and recited a particular portion of Surrah Maryam upon the inquiry of the Negus. On hearing the Qur'an, it is reported, "the Negus wept until his beard was wet and the bishops wept until their scrolls were wet." 26

Another short narration of Jesus' story occurs in chapter 5, Sürah Mā'îdah, where the narrator presents the events succeeding his birth and the period before ministry. It covers the period when Jesus starts performing those grand miracles traditionally associated with him within as well as outside the New Testament canon.

O Jesus the son of Mary! Recount My favour to thee and to thy mother. Behold! I strengthened thee with the Holy Spirit, so that thou didst speak to the people in childhood and in maturity. Behold! I taught thee the Book and Wisdom, the Law and the Gospel and behold! Thou makest out of clay, as it were, the figure of a bird, by My leave, and thou breathest into it and it becometh a bird by My leave, and thou healest those born blind, and the lepers, by My leave. And behold! thou bringest forth the dead by My leave. And behold! I did restrain the Children of Israel from (violence to) thee when thou didst show them the clear Signs, and the unbelievers among them said: 'This is nothing but evident magic.' (Sūrah Mā'īdah 5:110)

The Qur'an further systematizes its story by asserting that the miraculous birth of Jesus does not have to be approached

25 This exceptional occurrence came to pass during an event marked in the Islamic Calendar as the "Second Flight to Abyssinia" (616-617 CE).

${ }^{26}$ Muḥammad Ibn Isḥāq, Sìrat Rasūl Allah: The Life of Muhammad, trans. Alfred Guillaume (Oxford: Oxford University Press, 1955), 152. 
exclusively from the Christian doctrinal position. It offers an alternative argument for canonizing and defending the virginal birth and negating the associative "deity" connotation simultaneously, which emerged as a byproduct of the virgin birth concept in the conventional theology of the church. It posits the argument with such confidence that it merits quotation.

The similitude of Jesus before Allah is as that of Adam; He created him from dust, then said to him: “Be.” And he was! (Sūrah Āl 'Imrān 3:59)

The Islamic scripture does not offer much detail on the youth and pre-ministry period of the life of Jesus in comparison with, or contrast from the canonical Gospels. There is an identical silence in the Qur'an on the so-called "lost years" of the late childhood and early youth phases of Jesus' life just as it is the case in all four of the Gospels. ${ }^{27}$ Apart from the miraculous birth, the Qur'an deals with the life of Jesus in a way of presenting propositional argument by putting most of the statements about Jesus and his teachings into God's 'first person' monologic discourse. Jesus himself, on the contrary, only rarely makes appearance in a dialogue, and whenever he does so, the dialogue generally proceeds with God himself being the active speaker. A number of such dialogues occur in a post-Apocalypse setting, which, according to the Muslim theologians, is the final resurrection of the dead and is therefore referred to with such expressions as the "Day of Resurrection, Day of Recompense," and the "Last Day." 28 Jesus apparently assumes the role of a witness in the dialogic discourse of the Qur'an against those who have transgressed and committed the grave sin of shirk, "association of partners with God," in his name while laying the claim to follow his Evangel.

\footnotetext{
${ }^{27}$ For a study of the "lost years" from a Christian biblical perspective, see Dennis Price, The Missing Years of Jesus (Carlsbad, CA: Hay House, 2010), 1-4.

${ }^{28}$ Ṭabarī, for instance, quotes Ibn 'Abbās, Abū Mālik, Ḥasan al-Bașrīi, Qatāda, and $\mathrm{Ibn}$ Zayd stating their common understanding of the return of Jesus towards the end of time that he will unite all the communities of the world in one religion, whereas the faith of the outsiders, including Jews, will be of no avail. Jesus will be a witness for and against those who believed and disbelieved. See Neal Robinson, Christ in Islam and Christianity (Albany, NY: State University of New York Press, 1991), 78-79.
} 
And [beware the Day] when Allah will say, "O Jesus, Son of Mary, did you say to the people, "Take me and my mother as deities besides Allah?'” He will say, "Exalted are You! It was not for me to say that to which I have no right. If I had said it, You would have known it. You know what is within myself, and I do not know what is within Yourself. Indeed, it is You who is Knower of the unseen. I said not to them except what You commanded me to worship Allah, my Lord and your Lord. And I was a witness over them as long as I was among them; but when You took me up, You were the Observer over them, and You are, over all things, Witness." (Sūrah Mā'idah 5:116-117)

\section{Christological Projection above Prophet-Messenger Threshold}

Even though the Qur'an offers sketchy details about Jesus, the Qur'anic voice certainly appears invested in ascertaining the characteristic difference between the prophetic ministry of Jesus and the ministries of the rest of the prophets the Islamic Scripture mentions. It stands out while analyzing the portrait of Jesus in Islam that the Qur'an singles out Jesus and ordains him above the ceremonial status of a prophet (Arabic, nabi) in the conventional sense. The conceptual thresholds of the word prophet in the JudeoChristian and the Islamic worldviews, therefore, need to be revisited to grasp the fundamental difference between the two positions. Prophecy in the Bible does not carry the same meaning and function as it does in the Qur'an. ${ }^{29}$ The Qur'an attempts to bring more understanding to the concept in question by bringing it near perfection; it does so by assigning the station of infallibility to the vocation of prophecy (Arabic, nabuwwah). ${ }^{30}$

The Qur'anic Jesus assumes the constituency of a higher designation than what is typically the Hebraic understanding of a prophet. Jesus is, it is believed, one of the five towering

29 Islam's "prophetic paradigm" bears critical differences in theological underpinnings versus the theologies of the Jewish Bible and the New Testament. See John Kaltner and Younus Mirza, The Bible and the Qur'an: Biblical Figures in the Islamic Tradition (New York: Bloomsbury T\&T Clark, 2018), 147-149.

${ }^{30}$ For instance, a prophet (نبى) does not commit deadly sins in the Qur'anic theorem-a concept that does not echo in the Bible and remains exclusively reserved for Christ himself. The Qur'an does acknowledge the "error of judgment" element among the Prophets and prefers to call it jă (zallah), "slip," rather than ذَنب (dhanb), "sin" (Sūrah Baqarah 2:36). For more on the subject, see Ibid., 147. 
personalities of the Qur'an along with Noah, Abraham, Moses, and Muhammad-some also add Adam to the fold. ${ }^{31}$ Prophecy, or prophethood, as Muslims call it, does not bear the same character in biblical tradition as it does in Islam in spite of the fact that both Hebrew and Arabic languages use the same noun for describing the station of prophecy. ${ }^{32}$ A prophet, in the Qur'anic theory, surrenders both his will and self to the will of God and acts, out of willful submission, in a manner of being God's mouthpiece. ${ }^{33}$ There is no warrant for a prophet to disobey or contradict a divine injunction within the Qur'anic worldview, nor can a prophet independently seek salvation for himself, his family, or any other individual. ${ }^{34}$ Prophets are typically raised among the people of their ethnicity and they speak the language of their countrymen, for the Qur'an repeatedly lays emphasis on the importance of clear communication through prophetic discourse for delivering the divine message: "We sent not a messenger except (to teach) in the language of his (own) people, in order to make (things) clear to them (Ibrāhīm 14:4)."

The Qur'an recognizes the person of the historical Jesus as alMasinh, "Christ," but his messianic ministry is viewed without universal application as exclusively aimed at reforming the nation of Israel. ${ }^{35}$ The Rhema and Logia of Christ, which technically fall within the divine communication slash revelation paradigm of the Qur'an, are recognized under the title of injīl, "Evangel" or "Good News." 36 The Qur'an declares that the injill given to Jesus bears

${ }^{31}$ Mustafa Akyol, The Islamic Jesus: How the King of the Jews Became a Prophet of the Muslims (New York: St. Martina's Press, 2017), 236.

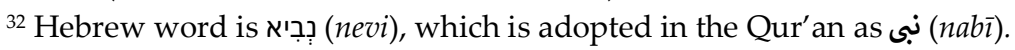

${ }^{33}$ Sūrah Najm 53:3-4

${ }^{34}$ For instance, see Sūrah Tahrīm 66:10, where the example of Noah and Lot's wives is cited. Both of them were the wives of celebrated prophets and yet it could not help them to earn salvation.

${ }^{35}$ Matthew 15:24 quotes Jesus saying: "I was sent only to the lost sheep of Israel." Mark 7:27 also references this position of Jesus. Matthew 10:5-6 is yet another important text to support this conclusion. Similarly, the Qur'an as well keeps Jesus within the house of Israel, among Jews, to maintain the historical dependence of Jesus' ministry on the national Jewish history. It portrays Jesus engaged in a dialectical argument with legalistic Jews. For instance, see Sūrah Zukhruf 43:63-64 and Sūrah Șaff 61:6.

${ }^{36}$ It is reminiscent of the Greek $\varepsilon \dot{v} \alpha \gamma \gamma \hat{\varepsilon} \lambda$ ıov. 
"light and guidance" from God for his followers. ${ }^{37}$ Notably, Islamic schools of theology and law stipulate that injil is the third book revealed by God in the line of four Abrahamic scriptures, which includes the Tawrāt, "the Law," Zabūr, "the Psalms," Injīl, "the Gospel," and finally the Qur'an itself. The Islamic scripture attempts to contextualize the ministry of Jesus in its historical framework and maintains that Jesus was raised to the office of prophecy in order to cleanse the Law of Moses from the legalism and corruption of Rabbinic Judaism. God had accorded him the knowledge of the Law through wahì, "revelation," and granted him profound insights into the consecrated Prophetic Writings and the Wisdom literature. Such a progression of revelation from Moses to Jesus, therefore, culminated in the gospel message handed down to Jesus, which was later proclaimed to be the divine decree for the religious outlook of the Jewish and pagan worlds of Judea and Hellenistic Rome. ${ }^{38}$

From the standpoint of ethics and civility, moreover, the Qur'an speaks of Jesus in high terms and grants him the highest standard of moral perfection and spiritual purity. ${ }^{39} \mathrm{He}$ is portrayed bearing a unique moral perfection that no other character in the Qur'an is endowed with. Such exclusive traits, in fact, echo the New Testament Jesus, particularly that of John's theological characterization of the historical Jesus. Such a scenario seems to make a case for the critical view that John's principle of Logos

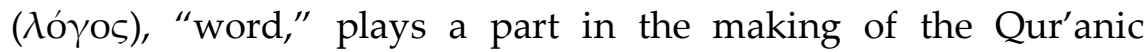
Jesus. ${ }^{40}$ Jesus is, for instance, spoken of in the Islamic scripture as kalimah, "a word," from Allah. In the Qur'anic context, the word kalimah is a creative-imperative, "Be," which was historically uttered at the outset of the creation scheme and thus the creation

${ }^{37}$ Sūrah Mā'idah 5:46: "And in their footsteps We sent Jesus the son of Mary, confirming the Law that had come before him: We sent him the Gospel: therein was guidance and light, and confirmation of the Law that had come before him: a guidance and an admonition to those who fear Allah."

38 Sūrah Āl ‘Imrān 3:48; Sūrah Mā’idah 5:110.

39 Sūrah Maryam 19:19.

${ }^{40}$ In the beginning was the Word, and the Word was with God, and the Word was God. He was with God in the beginning. Through him all things were made; without him nothing was made that has been made. In him was life, and that life was the light of all mankind. (John 1:1-4) 
"was." ${ }^{41}$ In this respect, however, the kalimah of the Qur'an comes closer to Philo's conceptualization of Logos in terms of resemblance than that of John's. It is noteworthy that some students of the Qur'an, particularly of Christian background, see a connection between the Logos of the Fourth Gospel's prologue and the aforesaid Qur'anic kalimah. ${ }^{42}$ Such a view, however, has been opposed by Muslims, because majority of the classical and modern commentators of the Qur'an insist that the term in question does not mean the Word of God; instead, it is a generic rendering of the divine principle of creation recognized in the Qur'an with the Arabic word kun, "Be," and can only mean "a word of God" in Jesus' case. ${ }^{43}$ This interpretation will, in all likelihood, make more sense when it is understood in the light of the example of a fundamental theological difference between Logos and Rhema in a Christian worldview glanced at through biblical scholarship.

The Qur'an proceeds with its argument to build a case for the humanity of Christ while incorporating such important terminology and titles as listed above.

O People of the Book! ${ }^{44}$ Commit no excesses in your religion: Nor say of Allah aught but the truth. Christ Jesus the son of Mary was (no more than) an apostle of Allah, and His Word, which He bestowed on Mary, and a spirit proceeding from Him: so believe in Allah and His apostles. Say not 'Trinity': desist: it will be better for you: for Allah is one Allah. Glory be to Him: (far exalted is He) above having a son. To Him belong all things in the heavens and on earth. And enough is Allah as a Disposer of affairs. (Sūrah Nisā $4: 171)$

One exceedingly important aspect of the character of Jesus in the Qur'an is that he is listed among the $\bar{u} l u$ al-'azm anbiyā, "Arch-

${ }^{41}$ It is interesting to note that John the Baptist (Arabic, يحن - Yahiya) is also entitled to the same honorific title كلمة الله (kalimatullah), "a Word of God," in Sūrah Āl 'Imrān 3:38-39. For a further study of the kalimah concept, see my article: “The Qur'ānic Dialogue with the Mystical Theology of Logos in John's Gospel," Teosofi: Jurnal Tasawuf dan Pemikiran Islam 10, no. 2 (December 20, 2020): 179-203.

${ }^{42}$ Frederic Ntedika Mvumbi, The Identity of Christ in Islam (Nairobi: Paulines Publications, 2008), 94-95.

${ }^{43}$ Parrinder, Jesus in the Qur'an, 45-46. Țabarī and Rāzī take a similar approach to this subject. See Muhammad Asad, The Message of the Qur'an (London: Book Foundation, 2003), 156, footnote 4:171 and 89, footnote 3:39.

أهل الكتاب (ahl al-kitāb), "People of the Book," meaning the Jews and the Christians. It is sometimes translated as the "Followers of the Bible." 
Prophets," a category that includes a select lot of five prophesying messengers of God. ${ }^{45}$ In the Qur'anic model of faith and piety, critically speaking, this particular epithet is applied to a prophet trapped in a situation of trial and temptation wherein he stays steadfast and demonstrates perseverance retaining the highest level of faith and gratitude by submitting his will to the will of God. For such an elevated individual, faith and trust in God suffice as his ultimate strength and source of perseverance. ${ }^{46}$

The Qur'an makes another significant leap in its text and recognizes Jesus as rühullah, "breath/spirit of God." ${ }^{77}$ The rationale for employing this title for Jesus apparently has to do with the Qur'anic stratagem of appropriating the concept within Qur'anic theology against a rather mythical notion of a divine savior's preexistence (cf. John 1:14). In the Qur'an, such Christological ideas as preexistence, sonship, crucifixion, and resurrection are neglected and kept apart from the miraculous (virgin) birth, which the Christian theology had come to adopt long before Islam as a mandatory package for the ideal of Christ, the heavenly savior. ${ }^{48}$ The specific principle of miraculous birth is acceded to clear off Mary against Jewish accusation of misconduct by maintaining that Jesus was born without an earthly father and that his conception was a direct result of God's breath of life into Mary's womb. Contrarily, the Qur'an also uses the expression of blowing spirit i.e. breath of life when speaking of the creation of Adamplausibly the creation of humanity in general: "When I have fashioned him (in due proportion) and breathed into him of My spirit (Șād 38:72)."

Not unlike his wonder works in the New Testament, Jesus performs astonishing miracles in the Qur'an as well to outwit and shake his audiences' vision of phenomenology. Some of the

\footnotetext{
${ }^{45}$ Sūrah Shūrā 42:13.

${ }^{46}$ Compare this Qur'anic principle with temptation of Christ in the Synoptic Gospels.

${ }^{47}$ Sūrah Nisā 4:171 - The رُوح الله (rūhullah) epithet remotely corresponds with the accounts of both Matthew and Luke because Mary gets "pregnant through the Holy Spirit." (Matthew 1:18)

48 J. Gresham Machen, The Virgin Birth of Christ (Cambridge, UK: James Clarke \& Co., 1958), 53-55.
} 
miracles, interestingly, appear to have their origins in the extracanonical genre of the biblical literature called "Infancy Gospels." ${ }^{49}$ Echoing the New Testament, Jesus heals the leper and quickens the dead in the Qur'an as well. The New Testament ingredient of "exorcism" is, however, missing in the making of the Qur'anic Jesus Christ. Contrary to the New Testament's worldview, in fact, it is not the will of Jesus himself that is the source of his miracles per Qur'anic declaration, because his entire miraculous activity is commissioned by God himself (Arabic, biidhni'llah), and thus God alone is the original source.

And (appoint him) a messenger to the Children of Israel, (with this message): "'I have come to you, with a Sign from your Lord, in that I make for you out of clay, as it were, the figure of a bird, and breathe into it, and it becomes a bird by Allah's leave: And I heal those born blind, and the lepers, and I quicken the dead, by Allah's leave; and I declare to you what ye eat, and what ye store in your houses. Surely therein is a Sign for you if ye did believe." (Sūrah Āl ‘Imrān 3:49)

The Qur'an further maintains that Jesus is raised within the Mosaic covenant and therefore he is a follower of the Torah like any other member of the Jewish nation. Jesus is portrayed to have upheld and confirmed the Law of Moses as the ultimate path of salvation and thus consecrates it as the Word of God and guidance for the children of Israel..$^{50}$ The ministry of a Law-abiding Jesus is directly transitioned into a powerful futuristic role, which originates in the Qur'an but develops outside it. Islam's concept of apocalypse is, in fact, incomplete without the person of Jesus. Although most of the details about the "Second Coming" of Jesus occur in the hadith literature, Jesus is spoken of in the Qur'an as a "sign" of the Hour - the Day of Judgment. The Qur'an confirms it in chapter 43 in the following words:

${ }^{49}$ Jan A. B. Jongeneel, Jesus Christ in World History (Frankfurt: Peter Lang, 2009), 128.

${ }^{50}$ Sūrah Āl 'Imrān 3:49-50. A discernable New Testament context is available to this particular understanding of the role of Jesus in Islam. Matthew 5:17, for instance, describes the role and ministry of Jesus as Law-centered. Matthew quotes Jesus in the following words: "Do not think that I have come to abolish the Law or the Prophets; I have not come to abolish them but to fulfill them." 
And (Jesus) shall be a Sign (for the coming of) the Hour (of Judgment): therefore have no doubt about the (Hour), but follow ye Me: this is a Straight Way. (Sūrah Zukhruf 43:61)

The above verse becomes the main platform for all of the subsequent evolution and embellishment of Islam's messianic view of Jesus. The subject of Jesus' messianic role, therefore, occupies the central stage in the secondary layer of Islamic literature with reference to the predominant vision of apocalypse.

When revisiting the teachings of Jesus, the Qur'anic voice appears to be resolute in adopting an antithetical stance to such teachings of the New Testament as might be, academically, viewed as nonJewish or Pauline. ${ }^{51}$ It does not acknowledge that Jesus preached his own "deity" and commanded - or even allowed - his followers to "worship" him. As a matter of fact, the Qur'an's rejection of the doctrine of Trinity is a key component of its theological disposition towards Christianity, for it views Trinity as a disgrace-a stain of paganism - to the holiness, omnipotence, and unity of God. ${ }^{52}$ The transcendent God of the Qur'an is deeply-and at times exclusively-concerned with his absolute oneness, which, the Qur'an maintains, is "blasphemed" if it is voiced through a polytheistic doctrine, such as Trinity. ${ }^{53}$ The Qur'an, therefore, takes a step further and advises the ahl al-kitäb, "People of the Book," to refrain from using a theologically flawed expression, three (or trinity), to describe the nature of the unity of Godhead. To this end, the Qur'an emphasizes the following:

Say not 'Trinity'; desist: it will be better for you: for Allah is one, only Allah. ${ }^{54}$ (Sūrah Nisā 4:171)

${ }^{51}$ Although the Qur'an does not mention Paul or any other apostle of Christ by name, it does take into consideration the transition from the Law-centeredness to an open, less disciplined view of religious life.

${ }^{52}$ Minim A. Sirry, Scriptural Polemics: The Qur'ān and Other Religions (New York: Oxford University Press, 2014), 133, 165.

${ }^{53}$ Sūrah Mā'idah 5:73

${ }^{54}$ Similarly, the Qur'an again enunciates in Sūrah Mā'idah 5:73: “They do blaspheme who say: Allah is one of three in a Trinity: for there is no god except One Allah." The Christian Trinity is a complex doctrine, so much so that even Christian theologies are unsure whether they uphold modalism, tritheism or subordinationism. The Qur'an puts it into the category of polytheism. 


\section{Skeptical Approach to Crucifixion and Resurrection}

It is an orthodox Islamic position that Jesus was not crucified. ${ }^{55}$ It is believed that Jesus survived the Roman crucifixion because God intervened to protect him against the Jewish conspiracy and commissioned his ascension into heavens; this is the most likely exegetical scenario that the only reference to the crucifixion in the Qur'an seems to point out (Nisā 4:157-158). The question as to how he survived the crucifixion has never been properly exhaustednor historically answered-because the Qur'an is silent on this subject, whereas the hadith does not yield conclusive details either. There are various theories in circulation about the escape of Jesus, which, by and large, emanate either from the Islamic Hebraic tradition, the so-called isrā'iliyāt, or from some obscure and weakly supported prophetic traditions, ahadith. ${ }^{56}$ The most prominent among such exegetical theories is called the "Substitution Theory," which is almost universally hinged upon by Muslims from humble religious positions to the highest echelons. This theory purports that a certain other individual was substituted for Jesus in the moments of chaos that erupted before the event of cross. ${ }^{57}$ However, it is important to note that no such claim can be traced from within the Qur'an itself. The Qur'an mentions the crucifixion event in only one verse where it denies the crucifixion as well as killing of Jesus in a counterclaim to the Jewish boast of having killed the "(perhaps, self-appointed) Messiah and envoy of God." It adopts a polemical approach towards Jewish boastfulness in order to check and condemn the act of bragging about killing Jesus and declares them a misled multitude that follows "delusions."

55 The use of the term "orthodox" requires some clarification here because a modern religion of Islamic background, Ahmadiyyah, from the Indian Subcontinent claims that Jesus died a natural death and Ghulām Aḥmad of Qādiān, the founder of the sect, is the second coming of Christ. See Hasanat Ahmad Syed, The Second Coming of Jesus Christ (Bloomington: iUniverse, 2009), 38-41.

${ }^{56}$ Hadìth and isrä'îliyāt represent two different genres within Islam's religious literature. See Jonathan Brown, Hadith: Muhammad's Legacy in the Medieval and Modern World (Oxford, UK: Oneworld, 2009).

57 Chawkat Moucarry, The Prophet and the Messiah, An Arab Christian's Perspective on Islam and Christianity (Illinois: Intervarsity Press, 2001), 135. 
That they (the Jews) said boasting, "We killed Christ Jesus the son of Mary, the Messenger of Allah." But they killed him not, nor crucified him, but so it was made to appear to them, and those who differ therein are full of doubts, with no (certain) knowledge, but only conjecture to follow, for of a surety they killed him not. Nay, Allah raised him up unto Himself; and Allah is Exalted in Power, Wise. And there is none of the People of the Book but must believe in him before his death; and on the Day of Judgment he will be a witness against them. (Sūrah Nisā 4:157-159)

Various interpretations have been offered for this obscure passage from within and outside Islamic tradition. At times, commentators have also ventured to take these verses, especially when viewed in the light of Sūrah 3:55, as a tacit affirmation of the crucifixion as a historical event while denying only the part that the Jews have claimed to play in it. ${ }^{58}$ Christian polemicists usually treat the above verses of the Qur'an as having borne the influence of Docetism-potentially an influential candidate for spreading Gnosticism in the Near East and Arabia in the history of late Christian Gnosticism towards Late Antiquity. ${ }^{59}$

The Qur'an does not appear to have been familiar with the Christian doctrine of the "resurrection" of Jesus. In fact, the Qur'an lacks the tomb image in toto, let alone a mention of the empty tomb visited by the female follower(s) of Jesus at or after his resurrection. The Qur'anic Jesus does not die on the cross in order to have to descend into the tomb for the ultimate test of his resurrection - a definitive proof of his divinity for the church. He is taken up by his Lord (Arabic, Rabb) unto himself, which majority of the Qur'anic commentators believe is a place in the highest heavens. ${ }^{60}$

Those who differ therein are full of doubts, with no (certain) knowledge, but only conjecture to follow, for of a surety they killed him not. Nay, Allah raised him up unto Himself; and Allah is Exalted in Power, Wise. (Sūrah Nisā 4:157-158)

The theology of the Qur'an is altogether devoid of the word "Father" with reference to the creator God. The structure and

\footnotetext{
${ }^{58}$ Robinson, Christ, 108-109.

${ }^{59}$ Khalidi, The Muslim Jesus, 12.

60 Sayyid Abul A'la Mawdudi, Towards Understanding Islam, trans. Zafar Ishaq Ansari (Leicester, UK: The Islamic Foundation, 2007), 143.
} 
terminology both completely ignore the New Testament word $a b b a$, "father" in relation to human invocation. Moreover, the New Testament expression "Father in Heaven" is fundamentally alien to the linguistic structure of the Qur'an, because the word Allah for God is indistinctly employed throughout the sacred text-even within the context of the patriarchs and prophets of the ancient, such as Noah, Abraham, Joseph, Moses, and David. Such a conspicuous use of the key terminology is grounded in the theological framework of the Qur'an where no distinction is made, except for the special case of virgin birth and distinct miracles, between the designated prophets and messengers and Jesus thus shares the fundamentals of humanity, provenance of revelation, and essential characteristics of his ministry with other prophets. ${ }^{61}$

The denial of Jesus' crucifixion - and by default that of his subsequent resurrection - has been an orthodox doctrine among Muslims ever since the writing and redaction of the Qur'an's classical commentaries. It is plausible, however, that the doctrine of ascension-beyond-crucifixion did not start off within the same theological character in the lifetimes of the Prophet Muhammad. It is also probable that the first generation after Muhammad believed in relatively different details about Jesus' final events than those canonized and dogmatized afterwards during second and third generations of posterity. From a historical-critical point of view, one might argue that such a characterization of the Islamic Jesus was an aftermath of Judeo-Christian linguistic and theological influence on Islam's evolving thought, particularly, under the Damascus Caliphate of Umayyad Dynasty. ${ }^{62}$

\section{Gospel, According to the Qur'an}

The injīl, "Evangel" - more commonly "Gospel" - according to the Qur'an, is a radically different concept from that of the New Testament's conception and transmission of the Gospel of Jesus

${ }^{61}$ Say: "We believe in Allah, and in what has been revealed to us and what was revealed to Abraham, Ishmael, Isaac, Jacob, and the Tribes, and in (the Books) given to Moses, Jesus, and the Prophets, from their Lord: We make no distinction between one and another among them, and to Allah do we bow our will." (Sūrah Āl ‘Imrān 3:84)

${ }^{62}$ Jongeneel, Jesus Christ, 128. 
Christ. The Qur'an's reference to the Gospel, theologically, dwells on an abstract concept, which is not grounded, per se, in the history of Christian thought. It is important to understand the dichotomy here that Muslim scholars, more often than not, treat the Qur'anic reference to the Gospel of Jesus as identifiable with the New Testament itself, which, simultaneously, is believed to have been corrupted over the course of time. ${ }^{63}$ Such an approach is, however, tentative and superficial because the Qur'an itself yields little evidence to support such a thesis as identifying the New Testament with the injil and seems to back a radically different conclusion. By the time of the Prophet Muhammad's call to ministry, historically, Christianity, being an organized religion, was around six hundred years old, which does allow the Qur'an sufficient historical space to take a revisionist approach to the prior Christian history.

An important question, therefore, that begs answer in the present context is: what does the Qur'an mean by the use of the word injil, both semantically and theologically, and what is the message of Jesus within the scope of its theological worldview?

The Arabic rendition of the English word gospel is injill, which,

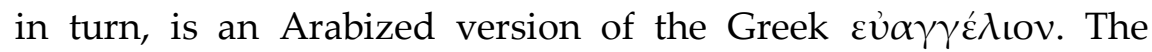
Qur'an has mentioned the word injil on twelve different occasions in the exclusive meaning of the special revelation accorded to Jesus, the son of Mary, the Christ. ${ }^{64}$ Arthur Jeffery, a noted Orientalist and the author of The Foreign Vocabulary of the Qur'an, suggests Ethiopic wangel as the possible origin of the word injil and claims that its "long vowel is almost conclusive evidence of the Arabic word having come from Abyssinia." 65 However, it is not known from any reliable source as to how and when the word in question entered into the Arabic language later on becoming injīl. The Arabic root for the noun injil is najala, which means "to draw water from" or "to father a child," and thus the word itself

\footnotetext{
${ }^{63}$ Oliver Leaman, The Qur'an: An Encyclopedia (New York: Routledge, 2006), 298.

${ }^{64}$ Parrinder, Jesus in the Qur'an, 145.

65 Arthur Jeffery, The Foreign Vocabulary of the Qur'an (Baroda: Oriental Institute, 1938), 72.
} 
implies posterity. ${ }^{66}$ The term adopted in the Qur'an for the Christ's revelation, nevertheless, encompasses the trajectory of both wahi "revelation/inspiration," and kitāb, "(divine) book" or "manifesto," which are considered to be the foundation of prophecy in the Islamic weltanschauung. While the word injil represents the revelation and/or manifesto of Jesus, there is yet another word employed in the Qur'an to signify "good news" in an identical lexical field as in the New Testament's use of the term gospel. The Qur'anic injīl is, therefore, given a vocal expression and an unequivocal meaning as the good news for posterity in one of the verses of Sūrah 61.

And remember, Jesus, the son of Mary, said: “O Children of Israel! I am the messenger of Allah (sent) to you, confirming the Law (which came) before me, and giving the Glad Tidings of a Messenger to come after me, whose name shall be Ahmad. ${ }^{67 "}$ But when he came to them with Clear Signs, they said, “This is evident sorcery! (Sūrah Șaff 61:6)

The Islamic scripture, therefore, highlights two different dimensions of the good news of Jesus, which apparently seems to bring more complication to the problem than positing a solution.

The second Arabic word used in this context is bushra (also, bashārā), meaning "good news," and it is this same root that is employed in the above quoted verse. Understanding the word within this particular context, as the Qur'an articulates, an important part of historical Jesus' gospel message was also to proclaim the coming of a prophetic-messenger after him. Therefore, there is no ambiguity involved, at least, in the ascertainment that the Islamic scripture has dealt with the Christian concepts and terminology on a relatively different lexical-and sometimes conceptual-threshold in order to adapt

${ }^{66}$ D.S. Margoliouth, Chrestomathia Baidawiana: The Commentary of El-Baidāwi on Sura III (London: Luzac \& Co., 1894), 2.

${ }^{67}$ Prophet Muhammad's first name given to him by his mother at his birth was Ahmad. The name Muhammad was given afterwards by his grandfather, 'Abdul Mutțalib. See Muḥammad Sulaimān Manșūrpūrī and Rafiq Abdur Rahman, Muhammad: Mercy for the Worlds (Karachi: Darul Ishaat, 2002), 274, 429. See also Muhammad Husayn Haykal, The Life of Muhammad, trans. Ismail Raji' alFaruqi (Kuala Lumpur, Malaysia: Islamic Book Trust, 2008), 52-53. 
them to its own fundamental ideological and theological frameworks.

The Muslim scholarship of Biblia Hebraica and Christology attempts to trace the connection of the Qur'anic gospel, as employed and articulated in Sürah Saff 61:6, with the Paraclete ( $\pi \alpha \varrho \alpha ́ k \lambda \eta \tau O \varsigma)$ of John 14:16.68 Similarly, the $7^{\text {th }}$ chapter of the Qur'an, Sūrah A'rāf, also alludes to this particular notion of the "good news" against a somewhat broader spectrum. ${ }^{69}$ There are many dimensions in which the Islamic scholars attempt to reconstruct the Qur'anic concept of bushrā from the Christian thought, especially by engaging in an intertextual conversation with the Gospel of John, Synoptic Gospels, extracanonical literature, and writings of early Christians, which is, however, beyond the scope of the present topic. ${ }^{70}$

\section{Reception and Reworking of the End-Times Messiah Motif}

In spite of acknowledging Jesus as the messiah, the Qur'an nowhere does explicitly specify a primary or secondary messianic role of delivering a nation from oppression for Jesus throughout its text. It is evident from the Qur'an and various other genres of Islamic literature that the word messiah is used within a radically different and somewhat unique semantic and interpretive fields. The word, al-Masih , is built into a prophetic frame of reference within the Qur'anic discourse, which remains far removed from the salvific theology and high Christology of the New Testament. There is little evidence in the Qur'an to support the hypothesis that the Islamic scripture historically used the Arabic term al-Masin (משיח Hebrew) to mean what the writers of the New Testament

${ }_{68}$ Maulana Abdul Haq Vidyarthi, Muhammad in World Scriptures, vol. 1 (Columbus, OH: Ahmadiyya Anjuman Isha'at Islam Lahore Inc., 1999), 382-383.

69 "Those who follow the Apostle (of Allah), the unlettered Prophet, whom they find mentioned in their own (scriptures),- in the law and the Gospel." (Sūrah A'rāf 7:157)

70 The trend of benefiting from Judeo-Christian sources and giving credence to the historical details therein, which had faded away in the medieval era, is again gaining currency among Muslim religious and historical scholarship, especially within academia. To this end, some have taken the path of revisionism, whereas others prefer to stay within traditional Islamic narrative. 
thought of the term in question to have meant in the first century. The Qur'an took the appellation of al-Masìh as either a personal name of Jesus or his honorary title based on his attributive anointment in the role of the culminating messenger of God to the house of Israel. ${ }^{71}$

The whole concept of the conventionally messianic role of Jesus in Islam was, historically, a result of the religious evolution triggered after Muslims' dramatic conquests over the lands of the Jews, Christians, and Zoroastrians, namely Persia and Syria, wherein the messianic Jesus sprang up ipso facto in the subsequent development of Islam's religious thought. ${ }^{72}$ We cannot state with absolute certainty whether the Prophet Muhammad himself ever believed or taught about the second coming of the historical Christ, the Son of Mary. Yet it was not an independent ontogenesis of a messianic Jesus outside the Qur'an; instead, the concept did indeed find a couple of vague references within the Qur'anic text to lay its groundwork. The Qur'an, for instance, only vaguely hints at the messianic notion on two such places where the role of Jesus is apparently stretched out to the apocalypse and the trial of the Day of Judgment.

And there is none of the People of the Book but must believe in him before his death; and on the Day of Judgment he will be a witness against them. (Sūrah Nisā 4:159)

And (Jesus) shall be a Sign (for the coming of) the Hour (of Judgment): therefore have no doubt about the (Hour), but follow ye Me: this is a Straight Way. (Sūrah Zukhruf 43:61)

Acclaimed English translator and commentator of the Qur'an, 'Abdullah Yousaf 'Ali, comments on Sūrah 43:61, saying: "This is understood by some commentators to refer to the second coming of Jesus in the Last Days before Resurrection."73

The rest of the development and embellishing of Jesus' Messianic figure is, more or less, indebted to the early acquaintance and adoption of the Hebraic literature into Islam.

\footnotetext{
${ }^{71}$ Sūrah Āl ‘Imrān 3:49-50.

${ }^{72}$ Khalidi, The Muslim Jesus, 18.

73 'Abdullah Yousaf 'Ali, The Meaning of the Holy Qur'ān, New Edition. (Beltsville, Maryland: Amana Publications, 1999), 1276.
} 
This particular assortment of literature was soon afterwards tossed under the heading of isrä'îliyāt, "Hebraic Traditions." ${ }^{74}$ Moreover, an important role was played by the Syriac and Coptic lore in dressing the cloak of an apocalyptic role on Islamic Jesus. ${ }^{75}$ Quite surprisingly, Jesus is not the only messianic figure that has made appearance in Islam's apocalyptic literature. In Islamic eschatology, there is yet another, rather more powerful, messianic figure with a purely Islamic orientation known as al-Mahdi, "the Guided One."76 Al-Mahdi emerged as a byproduct of the Islamization of Christian second coming doctrine within a few decades of the Prophet Muhammad's death. Such an innovation was, from a sociological perspective, aimed at gratifying the insatiable desire of messianic-minded Muslims for a Muslim messiah. ${ }^{77}$ This particular situation was even more obvious in the late seventh century Syria where the aristocratic Arabs interacted and debated with dogmatically entrenched Christian subjects and realized the significance of a messianic deliverer. ${ }^{78}$

The following is an important hadith account from the authentic collection, which notes how the ruling Muslim mind eventually achieved a psychological superiority over Christianity by adding a messianic figure of their own above the Christian Christ.

74 Abdelwahab Meddeb and Benjamin Stora, A History of Jewish-Muslim Relations (Princeton, NJ: Princeton University Press, 2013), 628.

75 Sydney H. Griffith, The Bible in Arabic (Princeton, NJ: Princeton University Press, 2013), 27.

${ }^{76}$ For an academic study of al-Mahdī from a Twelver Shi'⿳亠丷厂 perspective, see Abdulaziz Abdulhussein Sachedina, Islamic Messianism: The Idea of the Mahdi in Twelver Shi'ism (Albany, NY: State University of New York Press, 1981). For a Sunnī take on the subject, see Muhammad Tahir al-Qadri, The Awaited Imām Mahdī (Lahore: Minhaj al-Quran Publications, 2017).

77 Ignaz Goldziher, Mohammed and Islam (New Haven, CT: Yale University Press, 1917), 244-247.

${ }^{78}$ Griffith, The Bible in Arabic, 101. 
What will be your feelings when the son of Mary will come down to you and your Imam (spiritual leader) will be from amongst you (in spite of Jesus' presence)! ${ }^{79}$

Interestingly, Islamic literature on the second coming of Jesus is prodigiously large. Its immensity in comparison with the canonical and extracanonical Christian literature is surprising. A few of those accounts of Jesus' messianic role, for instance, are listed below to analyze the phenomenon and develop a better familiarity with the subject of Jesus' descension to earth as perceived and laid out in the worldview preserved in the hadith.

1. The Messenger of Allah said: "There is no prophet between me and him (Jesus). He shall descend (from heaven). You should recognize him when you see him. He is a man of medium height, (his complexion) is between reddish and white; he will be between (or dressed in) two slightly yellowish garments; his head looks as if it is dripping water even though it is not wet. He will fight the (evil) people in the cause of God's religion, will break the Cross and kill the swine and abolish jizyah (tax on Jews and Christians); and Allah will put an end to all religious paths except Islam during his time. He will slay the Antichrist and will stay in the World for 40 years. Then, he will die and the faithful will perform the funeral prayer for him. ${ }^{80}$

2. The Messenger of Allah said: "In the meantime, while the Antichrist will be busy doing this and this, Allah will send down the Messiah son of Mary. He will descend in the eastern part of Damascus, near the white minaret (tower), dressed in the two yellow garments, with his hands resting on the arms of two angels. When he will bend down his head, water drops will appear trickling down, and when he will raise it, it will appear as though pearl-like drops are rolling down. Any disbeliever whom the air of his breath reaches, and it will reach up to the last

79 Sahị̄h Bukhārī, Book 60 ("Sayings and Teachings of Prophets"), Hadīth No. 3449 - This account rhetorically establishes that the spiritual leader of the Muslim community will enjoy authority also over Jesus when he returns.

80 Sunan Abū Daw' ūd, Book 37 ("Trials and Fierce Battles"), Hadīth No. 4310. 
limit of his sight, will fall dead. Then, the son of Mary will go in pursuit of the Antichrist, and will overtake him at the gate of Lud, and will kill him." 81

3. The Messenger of Allah said: "The Antichrist will appear in my Ummah (community), and will live for forty. Then Allah will send Jesus, the son of Mary. He will closely resemble 'Urwah ibn Masūd (a companion of Prophet Muhammad). Then he will pursue him (Antichrist) and kill him. Then, for seven years, the people will live in such a state that there will be no ill-will or enmity between any two individuals of them. ${ }^{82}$

The critics of hadith are not in consensus about the provenance and subtext of such assorted messianic accounts. But what can be determined nonetheless with a relatively higher degree of certainty is that such a wide range of accounts on apocalypse and eschatology can in no way, in their entirety, be a product of pure imagination and speculation. The question as to how much there was in the storehouse of the church tradition, folklore, popular culture, and apocryphal literature of the Eastern churches across the Christian belt in seventh century is open to debate even today.

It is no less than a surprise, on the other hand, that the earliest Arabic lectionary of the church, or a partially complete Arabic version of the Bible, appeared at least two centuries after the death of Islam's prophet. ${ }^{83}$ How could Muhammad have gained access to such a large amount of both oral and written Christological and apocalyptic materials, scattered from Egypt through Levant, and across the West Sahara, which the Arabs called al-Maghrib, might never be answered with accuracy.

A third voice proposes a potentially more pragmatic solution to this historical puzzle. Since the Qur'anic text is completely devoid of explicit messianic references-except for the two ambiguous references listed above-to the future return of Jesus Christ, it is often believed that various messianic concepts, such as

81 Sahịh al-Muslim, Book 19 ("Accounts of the Antichrist and His Features"), Hadīth No.7015.

82 Sahịh al-Muslim, Book 54 ("The Book of Tribulations and the Signs of the Last Hour"), Hadìth No. 7023.

${ }^{83}$ Khalidi, The Muslim Jesus, 21. 
found in both hadith and tafsìr, crept into developing Islamic stream of thought from the Christian world, particularly through Syria and Egypt. Syria was the fertile land of learning where the first Islamic dynasty of Caliphs, Banū Umayyah, rose to power and had their seat of government established at Damascus. ${ }^{84} \mathrm{~A}$ gigantic corpus of Islamic messianic and Hebraic literature thus came into being in the outcome of Muslims' intellectual engagements in the Christian enclaves in a period stretching over a hundred years after the death of the Prophet Muhammad. This particular reflex crystallizes a crucial change in the Muslim community's disposition during the legislation and legalization process under Umayyad Dynasty whose administrative needs allegedly brought about the introduction of several radically new ideas in Islam under the influence of Christian officials that staffed the Umayyad Empire. ${ }^{85}$ It goes without saying that the Umayyad era set in motion the future course of Islam's messianic thoughtprocess, whether it is traced within the Sunnī schools or the Shī'ah tradition, that created space for the emergence of the ideals of alMahdī and al-Masīh in parallel.

The Judeo-Christian vision of a messiah, particularly, originates from two important books of the Old Testament, Isaiah and Daniel. For instance, Book of Daniel, chapter 7 and 9:20-27, and Isaiah 7:14, 9:6, 11:2, 28:16, 40:3-5, 42:1-4, 50:6, and 53:3-12, etc. are understood to be direct allusions to a divinely guides future messiah to be raised from within the house of Israel. ${ }^{86}$ The difference between Judaism and Christianity, however, occurs at the interpretation level, where the Christian religion decides to take a radically different route from rabbinic Judaism and views the historical person of Jesus in a new theological light as the fulfillment of the messianic prophecies of the Old Testament.

${ }^{84}$ Nicholson Reynold, A Literary History of the Arabs (New Delhi: Purana Books, 2006), 145.

${ }^{85}$ Youssef M. Choueiri, ed., A Companion to the History of the Middle East (Malden: Blackwell Publishing, 2005), 48.

${ }^{86}$ Isaiah 11:1 mentions Jesse, King David's father, as the progenitor of the messiah in the following words: "A shoot will come up from the stump of Jesse; from his roots a Branch will bear fruit." Gospel of Luke 1:31-33 claims its fulfillment on the person of Jesus. 
Historically, the Christian New Testament brought to bear the religious ethos of the prophecies of ancient Jewish oracles designing a messianic life of Jesus that would play a pivotal role in a soteriological framework of the new religious movement. ${ }^{87}$ In other words, the only possible way for Christianity to accept the promised messiah was within that salvific framework, which would, in turn, establish the uniqueness and supremacy of Christ embedded in the exclusiveness of his traits from virgin birth to crucifixion and from resurrection to the second coming, which all, in the Christian view, point back to Christ's divinity (John 1:1) and power to grant salvation (Matthew 9:2-7). The Jews, on the other hand, rejected this Christian interpretation of the Old Testament prophecies and continued to wait for their prophesied messiah pushing the Jewish religion directly into the phase of eschatology.

Islam, like rabbinic Judaism, does not acknowledge the Christian concept of messiah developed within the New Testament's Christological paradigm. But the Qur'an does, nonetheless, recognize certain historical and spiritual aspects of the New Testament Christ, which, at the very least, brings about a basic affinity between Islam and Christianity. Such an approach of a partial recognition-rather than a total denial-makes both religions share certain common beliefs about the person of Jesus and his Christhood actuating a platform of ideological interaction. Despite its recognition of the New Testament Jesus' virgin birth, miracles, and a special role dispensed towards future, however, Islam vehemently opposes the assumption that such unique virtues of Christ inherently or subtly build a case for his divinity. The second coming of Jesus, therefore, bears a different meaning altogether and that one of the probable end-goals of such a promised apocalyptic event might be the confirmation of the message of Islam according to the hadith. ${ }^{88}$

There can be no denial on historical grounds that the EndTime messiah motif was adopted in Islam from the church

87 The Gospel writers helped Jesus fulfill prophecies using a hypothetical Coptic source called testimonia. See Robert J. Miller, Helping Jesus Fulfill Prophecy (Cambridge, UK: The Lutterworth Press, 2016), 123-124.

${ }^{88}$ Oddbjørn Leirvik, Images of Jesus Christ in Islam, 2nd ed. (New York: Continuum International Publishing Group, 2010), 39-41. 
tradition as a direct result of the Christian influence found in the intellectual and physical territories of Islam's emergence and spread. But what is equally important to understand is that the doctrinal position the Christian church had come to take was dispelled and declared anti-monotheistic in Islam's appropriation of the doctrine of messiah with reference to both his historical first coming and the eschatological second coming.

\section{Conclusion}

In conclusion, it may be stated in the light of this article's findings that the Christology of the Qur'an is a radical step towards the realization of a futuristic goal that is envisaged to be culminating on the unification of various Abrahamic faith traditions. The fact that Islam engages in a dialogue with the New Testament ideal of Christ through its scripture stands to reason that the future history of monotheistic faith tradition cannot ignore the critical role Jesus has been historically assigned in the transformation of the Western world from pure paganism to a full or a partial monotheism. Islam's own ideal of monotheism remains at work at the core of its religious paradigm, which, in principle, cannot allow to acknowledge the deified Jesus of the received tradition 'as is.' Islam has to set in motion, therefore, a process of modification and tweaking in order to not only recognize and inherit the figure of Jesus in historical terms, but also to make his role absolutely compatible with the theological confines of its own monotheistic worldview. The research in this article, therefore, upholds the position-and also substantiates the conclusion to confirm - that the Qur'anic Christology is radically different from the Christology of the New Testament and that the Qur'an offers a unique perspective on the subject in addition to yielding independent possibilities of research in the areas of Islamic Christology and Messianism.

\section{References}

Akyol, Mustafa. The Islamic Jesus: How the King of the Jews Became a Prophet of the Muslims. New York: St. Martina's Press, 2017.

'Ali, 'Abdullah Yousaf. The Meaning of the Holy Qur'ān. New Edition. Beltsville, Maryland: Amana Publications, 1999. 
Asad, Muhammad. The Message of the Qur'an. London: Book Foundation, 2003.

Barker, Gregory A., and Stephen E. Gregg. Jesus Beyond Christianity: The Classic Texts. Oxford: Oxford University Press, 2010.

Brown, Jonathan. Hadith: Muhammad's Legacy in the Medieval and Modern World. Oxford, UK: Oneworld, 2009.

Choueiri, Youssef M., ed. A Companion to the History of the Middle East. Malden: Blackwell Publishing, 2005.

Cornell, Vincent J. Voices of Islam: Voice of Tradition. Westport, CT: Praeger Publishers, 2007.

Dawud, 'Abdul Ahad. Muhammad in the Bible. Vol. 2 of Muhammad in World Scriptures. Kuala Lumpur, Malaysia: Islamic Book Trust, 2006.

Frilingos, Christopher A. Jesus, Mary, and Joseph: Family Trouble in the Infancy Gospels. Philadelphia, PA: University of Philadelphia Press, 2017.

Goldziher, Ignaz. Mohammed and Islam. New Haven, CT: Yale University Press, 1917.

Griffith, Sydney H. "Al-Nașārā in the Qur'an." In New Perspectives on the Qur'an: The Qur'an in Its Historical Context 2, edited by Gabriel Said Reynolds, 301-322. New York: Routledge, 2011.

- - . The Bible in Arabic. Princeton, NJ: Princeton University Press, 2013.

Haykal, Muhammad Husayn. The Life of Muhammad. Translated by Ismail Raji' al-Faruqi. Kuala Lumpur, Malaysia: Islamic Book Trust, 2008.

Ibn Isḥāq, Muhammad. Sìrat Rasūl Allah: The Life of Muhammad. Translated by Alfred Guillaume. Oxford: Oxford University Press, 1955.

Jeffery, Arthur. The Foreign Vocabulary of the Qur'an. Baroda: Oriental Institute, 1938.

Jongeneel, Jan A. B. Jesus Christ in World History. Frankfurt: Peter Lang, 2009.

Kaltner, John, and Younus Mirza. The Bible and the Qur'an: Biblical Figures in the Islamic Tradition. New York: Bloomsbury T\&T Clark, 2018. 
Khalidi, Tarif. The Muslim Jesus. Cambridge: Harvard University, 2001.

Klinghoffer, David. Why the Jews Rejected Jesus. New York: Three Leaves Press, 2005.

Lane, Edward William. Arabic-English Lexicon. Vol. 2. Cambridge: Islamic Text Society, 1984.

Leaman, Oliver. The Qur'an: An Encyclopedia. New York: Routledge, 2006.

Leirvik, Oddbjørn. Images of Jesus Christ in Islam. 2nd ed. New York: Continuum International Publishing Group, 2010.

Machen, J. Gresham. The Virgin Birth of Christ. Cambridge, UK: James Clarke \& Co., 1958.

Manșūrpūrī, Muhammad Sulaimān, and Rafiq Abdur Rahman. Muhammad: Mercy for the Worlds. Karachi: Darul Ishaat, 2002.

Margoliouth, D.S. Chrestomathia Baidawiana: The Commentary of ElBaidāwī on Sura III. London: Luzac \& Co., 1894.

Mawdudi, Sayyid Abul A'la. Towards Understanding Islam. Translated by Zafar Ishaq Ansari. Leicester, UK: The Islamic Foundation, 2007.

Meddeb, Abdelwahab, and Benjamin Stora. A History of JewishMuslim Relations. Princeton, NJ: Princeton University Press, 2013.

Miller, Robert J. Helping Jesus Fulfill Prophecy. Cambridge, UK: The Lutterworth Press, 2016.

Moucarry, Chawkat. The Prophet and the Messiah, An Arab Christian's Perspective on Islam and Christianity. Illinois: Intervarsity Press, 2001.

Mvumbi, Frederic Ntedika. The Identity of Christ in Islam. Nairobi: Paulines Publications, 2008.

Oaks Jr., W. Richard. The Cross of Christ. Lanham, MD: Lexington Books, 2020.

'Omar, 'Abdul Mannan. Dictionary of the Qur'an: Arabic-English. 2nd ed. Hockessin: Noor Foundation International, 2005.

Parrinder, Geoffrey. Jesus in the Qur'an. New York: Oxford University Press, 1977.

Price, Dennis. The Missing Years of Jesus. Carlsbad, CA: Hay House, 2010. 
Ratzinger, Joseph. Jesus of Nazareth: The Infancy NarrativesPublishing, 2012. Translated by Philip J. Whitmore. New York: Image Publishing, 2012.

Reynold, Nicholson. A Literary History of the Arabs. New Delhi: Purana Books, 2006.

Robinson, Neal. Christ in Islam and Christianity. Albany, NY: State University of New York Press, 1991.

Sachedina, Abdulaziz Abdulhussein. Islamic Messianism: The Idea of the Mahdi in Twelver Shi'ism. Albany, NY: State University of New York Press, 1981.

Shoemaker, Stephen J. Mary in Early Christian Faith and Devotion. New Haven, MA: Yale University Press, 2016.

Sirry, Minim A. Scriptural Polemics: The Qur'an and Other Religions. New York: Oxford University Press, 2014.

Syed, Hasanat Ahmad. The Second Coming of Jesus Christ. Bloomington: iUniverse, 2009.

Tahir al-Qadri, Muhammad. The Awaited Imām Mahdī. Lahore: Minhaj al-Quran Publications, 2017.

Vidyarthi, Maulana Abdul Haq. Muhammad in World Scriptures. Vol. 1. Columbus, OH: Ahmadiyya Anjuman Isha'at Islam Lahore Inc., 1999.

Waqas, Syed M. "The Qur'anic Dialogue with the Mystical Theology of Logos in John's Gospel." Teosofi: Jurnal Tasawuf dan Pemikiran Islam 10, no. 2 (December 20, 2020): 179-203. 